\title{
A meta-analysis on the association of genetic polymorphism of the angiotensin-converting enzyme and coronary artery disease in the chinese population
}

\author{
D Yongjun Zhang ${ }^{1}$ \\ (iD Tao Yang ${ }^{1}$ \\ Wenjiao Zhou ${ }^{1}$ \\ (iD) Yuee Huang ${ }^{2}$
}

1. Department of Electrocardiograph, Yijishan Hospital of Wannan Medical College, Wuhu 241001, China 2. School of Public Health, Wannan Medical College, Wuhu 241002, China

http://dx.doi.org/10.1590/1806-9282.65.6.923

\section{SUMMARY}

OBJECTIVE: To investigate the association between genotype insertion or deletion polymorphism of the angiotensin-converting enzyme gene (ACE) and susceptibility to coronary artery disease (CAD) in Chinese Han population.

METHODS: We conducted a comprehensive search for the OR value of contrast between the group of genotype insertion or deletion polymorphism of the ACE and the group of CAD as an effective index. A meta-analysis (Stata 12.0) was used to test the heterogeneity of the results, combine the values for effect, conduct sensitivity analysis, and basic evaluation.

RESULTS: A total of 638 studies were found on the association between polymorphisms of the angiotensin-converting enzyme gene and $C A D$, of which 44 studies met the inclusion criteria. In total, our study included 5619 cases and 4865 controls. The heterogeneity test of each study $(P<0.001)$ was carried out using a random effect model. The OR value of DD/ID+II was $1.95,95 \%$ confidence interval $(95 \% \mathrm{CI})(1.66-2.29)$. The OR value of II/DI+DD was $0.63,95 \% \mathrm{Cl}(0.55-0.72)$. The funnel figure is basically symmetrical and the results of the sensitivity analysis were stable.

CONCLUSION: The DD genotype of the angiotensin converting enzyme gene may be a weaker risk factor for CAD in the Chinese Han population.

KEYWORDS: Angiotensin-converting enzyme gene, Gene polymorphism. Coronary artery disease. Meta-Analysis.

\section{INTRODUCTION}

The pathogenesis of coronary artery disease (CAD) is unknown. The angiotensin-converting enzyme (ACE) is a key enzyme in the renin angiotensin system, which catalyzes the conversion of angiotensin I to angiotensin II and inactivates bradykinin. The hu- man angiotensin I converting enzyme gene is located on autosomal $17 q 23$, according to whether there is a $287 \mathrm{bp}$ sequence in its intron 16. It is divided into two types of alleles, insertion(I) and deletion(D), (ACE Gene I/D polymorphism). There are three genotypes 
(DD, II, ID) in human populations. Although the pathogenesis is still unidentified, recent studies showed that I/D polymorphism in intron 16 of the ACE gene is associated with CAD.

At present, a lot of research is being carried out on the relationship between ACE polymorphism and CAD, but no consensus has been achieved.

According to the results of a randomly chosen study by Camblen et al., ${ }^{1,2}$ the frequency of DD homozygous was significantly increased in patients with CAD compared to that in normal controls. The DD genotype was considered an independent risk factor for CAD, and ACE I/D polymorphism is closely related to Myocardial Infarction in Caucasians. However, a recent 2010 study that included 224 randomly chosen CAD patients of an Iranian population showed that there was no association between the DD genotype homozygote of the ACE gene and the risk of $\mathrm{CAD}^{3}$. Alazhary's et al. ${ }^{4}$ study on the Saudi Arabian population showed that the ACE gene DD homozygotes were not associated with the risk of CAD.

The distribution of genetic polymorphism varies in different races and populations. Over 3000 studies in our references pointed out that there is an obvious racial and regional difference in the distribution frequencies of ACE genotypes. For example, in Caucasians, DD was $36.25 \%{ }^{5}$. In the first generation of white immigrants living in London, DD was $23 \%$, $30.9 \%$ in the African population, $18.3 \%$ in South Asian population $^{6}$, and $8 \%$ in the Japanese population ${ }^{7}$. Studies in Chinese Han populations ${ }^{8}$

In the study of Jing et al. ${ }^{9}$, the results showed that the DD genotype was not associated with CAD in the Han population. They found that the DD genotype was associated with CAD in the Hui population, whereas it had no relation to the Han people. Therefore, it is of great significance and value to study the genetic polymorphism of ACE in the Chinese Han population. This study collected the relevant literature of the Chinese population for comprehensive quantitative analysis; a meta-analysis can control the heterogeneity of the study and the individual level of related factors to investigate the relationship between ACE and CAD.

\section{METHODS}

1.1 Literature search on Medline, Pubmed, CBM, Chinese Biomedical Literature Database and For- eign Biomedical Literature Journal Service system, etc. and keywords: Angiotensin-converting enzyme; Genetic polymorphism; Coronary artery disease; Evidence based medicine. Meta-Analysis to search for insertion/deletion of intron 16 of the ACE gene reported in China published before January 2018 on the relationship between I / D polymorphism and CAD disease risk.

1.2 Research Inclusion Criteria For the case-control study published independently in China, the literature needed to provide comprehensive statistical indicators: the case group was CAD, and the control group was the healthy population. The observation index was the odds ratio ( OR ) of the two groups of patients with genotype frequency, including ACE DD ( ID +II ) OR and II ( ID+ DD ) OR. Those who reported incomplete information or studies with only special samples, such as patients with myocardial infarction or CAD complicated with diabetes, or minority populations, as well as those in the control group that did not comply with the law of genetic balance were removed. If studies included the same sample of multiple literature reports, we selected the most recently published.

1.3 Quality assessment Two investigators independently screened the literature according to the predetermined inclusion and exclusion criteria. If there were disagreements that could be discussed or resolved by third parties in order to determine the methodological quality of the NOS, to Newcastle-Ottawa scale was used. The scale uses a "star rating" to determine the quality of the observational study, with NOS scores between zero and nine stars. A score higher than or equal to 7 points is considered to be high-quality literature, and the evaluation includes three items: the selection of the case group and the control group (4 points), comparability (2 points), and exposure (3 points).

1.4 Statistic treatment The Excel database was established by double input. The genotypes of the control group were tested using the Hardy-Weinberg (H-W) genetic balance test, and the database was statistically processed by Stata 12.0 analysis software, including OR value, 95\% confidence interval (95\%CI) and the heterogeneity test of each study. According to the test results, a fixed effect model or random effect model was selected to combine the data and a funnel chart was drawn for linear regression analysis to assess result bias. 
TABLE 1 CHARACTERISTICS OF STUDIES INCLUDED IN THE META-ANALYSIS

\begin{tabular}{|c|c|c|c|c|c|c|c|}
\hline \multirow[t]{2}{*}{ First author } & \multirow[t]{2}{*}{ Year } & \multirow{2}{*}{\begin{tabular}{|l} 
Region \\
(province/city)
\end{tabular}} & \multicolumn{2}{|c|}{ CAD patients } & \multicolumn{2}{|c|}{ non-CAD control } & \multirow{2}{*}{$\begin{array}{l}\text { NOS } \\
\text { score }\end{array}$} \\
\hline & & & Total & D frequency & Total & D frequency & \\
\hline Xiang et al.10 & 1995 & shanghai & 80 & 0.64 & 48 & 0.38 & 7 \\
\hline Kario et al.11 & 1996 & china & 276 & 0.409 & 147 & 0.411 & 8 \\
\hline Gu et al.12 & 1998 & beijing & 95 & 0.54 & 100 & 0.35 & 8 \\
\hline Shi et al.13 & 1998 & zhejiang & 148 & 0.446 & 159 & 0.425 & 7 \\
\hline Qiu et al.14 & 1999 & zhejiang & 73 & 0.58 & 102 & 0.38 & 8 \\
\hline Jia et al.15 & 1999 & jiangsu & 187 & 0.497 & 160 & 0.537 & 8 \\
\hline Sui et al.16 & 1999 & tianjing & 40 & 0.46 & 50 & 0.4 & 7 \\
\hline Tan et al.17 & 1999 & shandong & 137 & 0.639 & 63 & 0.436 & 8 \\
\hline Shi et al.18 & 2000 & tianjing & 169 & 0.583 & 94 & 0.441 & 8 \\
\hline Xie et al.19 & 2001 & jiangsu & 106 & 0.44 & 86 & 0.36 & 7 \\
\hline Chen et al.20 & 2001 & hubei & 51 & 0.422 & 30 & 0.3 & 8 \\
\hline Deng et al.21 & 2002 & sichuan & 55 & 0.34 & 102 & 0.36 & 7 \\
\hline Liu et al.22 & 2002 & jiling & 51 & 0.61 & 83 & 0.45 & 8 \\
\hline Su et al.23 & 2002 & jiangsu & 157 & 0.5637 & 112 & 0.3884 & 7 \\
\hline Zhu et al.24 & 2002 & jiangsu & 140 & 0.421 & 106 & 0.3585 & 8 \\
\hline Zhang et al.25 & 2003 & guangdong & 102 & 0.43 & 148 & 0.33 & 7 \\
\hline Huang et al.26 & 2003 & jiangsu & 89 & 0.567 & 75 & 0.413 & 8 \\
\hline Mao et al.27 & 2004 & hunan & 100 & 0.64 & 54 & 0.4537 & 7 \\
\hline Wang et al.28 & 2004 & hubei & 50 & 0.6 & 56 & 0.41 & 9 \\
\hline Zhu et al.29 & 2004 & beijing & 192 & 0.359 & 98 & 0.342 & 7 \\
\hline Lin et al.30 & 2005 & guangdong & 72 & 0.417 & 50 & 0.350 & 8 \\
\hline Wang et al.31 & 2006 & guangdong & 105 & 0.4381 & 50 & 0.32 & 8 \\
\hline Shi et al.32 & 2006 & zhejiang & 169 & 0.49 & 168 & 0.4167 & 9 \\
\hline Wang33 & 2006 & jiangxi & 161 & 0.56 & 109 & 0.46 & 7 \\
\hline Yang et al.34 & 2007 & sichuan & 80 & 0.581 & 80 & 0.413 & 7 \\
\hline Li et al.35 & 2008 & hebei & 80 & 0.63 & 100 & 0.62 & 8 \\
\hline jia et al.36 & 2008 & shanxi & 110 & 0.605 & 80 & 0.444 & 8 \\
\hline Shi et al.37 & 2008 & sichuan & 80 & 0.56 & 80 & 0.41 & 8 \\
\hline Zhao et al.38 & 2008 & shang hai & 115 & 0.46 & 47 & 0.34 & 8 \\
\hline Yun et al.39 & 2009 & hai nan & 150 & 0.46 & 150 & 0.343 & 7 \\
\hline Yang et al.40 & 2009 & xin jiang & 42 & 0.4405 & 82 & 0.36 & 7 \\
\hline Chen41 & 2009 & hu nan & 86 & 0.57 & 38 & 0.25 & 8 \\
\hline Xie et al.42 & 2009 & nei menggu & 94 & 0.367 & 67 & 0.358 & 8 \\
\hline Liu and $\mathrm{He} 43$ & 2010 & nei menggu & 54 & 0.6665 & 88 & 0.4886 & 7 \\
\hline Wang et al.44 & 2010 & jiang xi & 158 & 0.55 & 109 & 0.47 & 7 \\
\hline Yang et al.45 & 2011 & shan dong & 146 & 0.55 & 113 & 0.46 & 7 \\
\hline Peng et al.46 & 2011 & guang dong & 196 & 0.643 & 200 & 0.435 & 8 \\
\hline Yi et al.47 & 2011 & guang dong & 180 & 0.609 & 180 & 0.467 & 8 \\
\hline Wang et al.48 & 2012 & qing hai & 89 & 0.567 & 75 & 0.413 & 8 \\
\hline Hu et al.49 & 2013 & hu nan & 86 & 0.57 & 38 & 0.25 & 7 \\
\hline Zhao et al.50 & 2015 & he bei & 233 & 0.51 & 99 & 0.42 & 7 \\
\hline Zhang et al.51 & 2016 & liao ning & 568 & 0.345 & 580 & 0.267 & 8 \\
\hline Jing et al.52 & 2016 & qing hai & 59 & 0.305 & 193 & 0.35 & 8 \\
\hline Dai53 & 2017 & shan dong & 208 & 0.45 & 216 & 0.34 & 8 \\
\hline
\end{tabular}




\section{RESULTS}

Results of the Literature Search and Analysis of Research Quality

A total of 638 related research papers were retrieved. The genotype distribution of the control group in 11 papers did not conform to the Hardy-Weinberger (H-W) genetic balance test law and were removed; 44 papers were found to meet the requirements (Table 1). Among them, 8 were published in English (or in Chinese/English), 31 in Chinese only, and 5 were officially published master's theses. The published time of the literature was from 1995 to January of 2018, the study population was comprised of 5619 cases of 44 studies in more than twenty provinces/cities of China and 4865 normal control. The diagnosis of CAD cases in each study was in accordance with the WHO standard. The angiotensin-converting enzyme (ACE) genotyping was based on three internationally recognized genotypes of DD, II, and ID. The detection methods were polymerase chain reaction (PCR) and gel electrophoresis.

\section{Analysis Of Angiotensin Converting Enzyme} Genotypes

The $\mathrm{Q}$ values of $\mathrm{DD} / \mathrm{DI}+\mathrm{II}$ and II/DI +DD genotype heterogeneity test of ACE gene were 105.74 and 100.56 respectively $(\mathrm{P}<0.001)$ and the combined $\mathrm{DD} /$ (DI+ II) OR was 1.95, 95\%CI (1.66-2.29), $\mathrm{Z}=8.09$ (P
$<0.001)$ (Fig. 1). The combined II/ (DD+DI) OR was 0.63, 95\%CI (0.55-0.72) , Z=6.64, $(\mathrm{P}<0.001)$.

\section{Sensitivity Analysis And Bias Assessment}

Concerning the polymorphic susceptibility analysis of the gene, after removing the largest sample and applying a random effect model analysis, the OR value of the comprehensive effect of the DD genotype was $2.00,95 \% \mathrm{CI}(1.70-2.34), \mathrm{Z}=8.55(\mathrm{P}<0.001)$. The comprehensive OR value of the genotype II was 0.62 , 95 \% CI (0.54-0.71) Z=6.68 ( $\mathrm{P}<0.001)$.

According to the combined effect value of the three groups (sample size < 100, $100 \sim 200, \geq 200$ ) , the $\mathrm{Q}$ value for the DD/DI +II and II/DI +DD genotype heterogeneity test was $7.54(\mathrm{P}=0.023)$ and 11.98 $(\mathrm{P}=0.003)$; the $\mathrm{OR}$ value was combined with the random effect model. The OR value of combined $\mathrm{DD} /(\mathrm{DI}+\mathrm{II})$ was 1.92, $95 \% \mathrm{CI}(1.51-2.44), \mathrm{Z}=5.33$, (P $<0.001)$, and the OR value of combined II/ (DI+DD) was $0.66,95 \% \mathrm{CI}(0.51-0.86)(\mathrm{P}=0.002)$. The sensitivity analysis results were stable. A meta-analysis is an observational study, in which publication bias is very common. Among the 44 articles collected, 29 reported that ACE DD genotype was associated with the risk of CAD, and 15 were not associated with the risk of CAD. The funnel map (based on ACE (I / D) polymorphism and the $\mathrm{OR}$ value of CAD risk were drawn as the horizontal coordinate and the standard

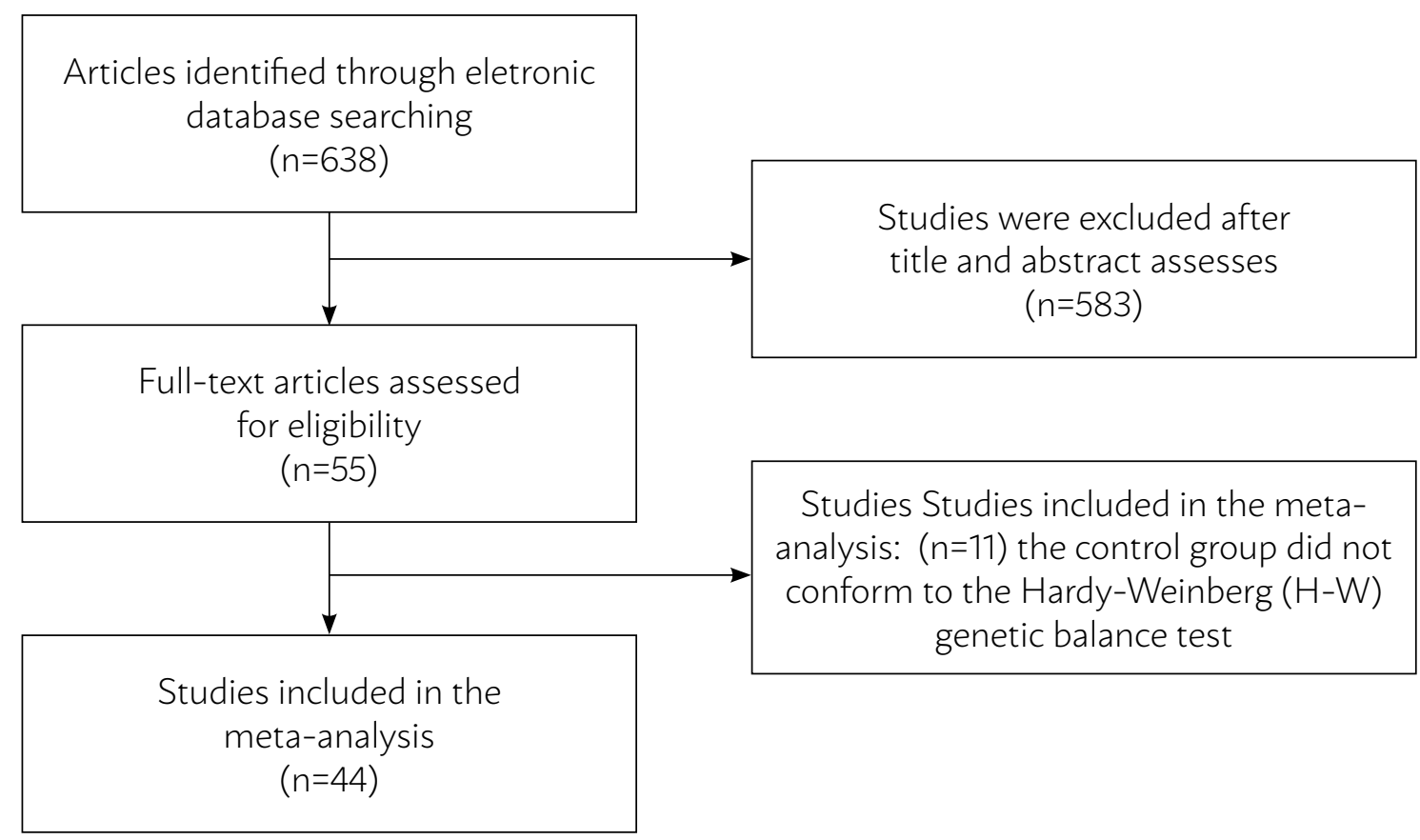


of OR value as the vertical coordinate ). The Egger linear regression analysis was used to test the symmetry of the funnel graph. The Y-axis intercept of the DD genotype was 2.17 (95\% CI 0.78-3.56 ) $\mathrm{P}=0.003$, and the II genotype was -2.47 (95\% CI -3.75 - 1.19), $\mathrm{P}<0.001$. According to the standard of $\mathrm{P}=0.1$, the two funnel graphs were both asymmetrical.

\section{DISCUSSION}

A total of 44 works of literature published in the past more than twenty years was included, with 5619 cases and 4865 controls. A meta-analysis revealed that ACE gene insertion/deletion (I / D) polymorphism was correlated with the risk of CAD in the Chinese Han population. The risk of CAD in individuals with DD genotype increased by $95 \%$ compared with the DI/II genotype. There is evidence that the DD genotype may increase the risk of left ventricular hypertrophy after myocardial infarction ${ }^{54}$, and the incidence of chronic heart failure in patients with CAD who carried DD genotype and D allele increased significantly. Moreover, the genotype can be used as a marker for the deterioration of cardiac function ${ }^{55}$. Studies have shown that the change of single nucleotide polymorphism of ACE gene increased the level of angiotensin II (Ang II) and bradykinin in peripheral or local circulation by influencing the level of ACE expression, which stimulates the release of aldosterone in blood vessels and enhances the re- lease of norepinephrine from sympathetic nerves. Consequently, the process of local inflammatory response in patients with atherosclerotic CAD was affected, and the process of atherosclerosis was aggravated ${ }^{56}$. The DD genotype was clearly associated with acute coronary syndrome, especially in acute myocardial infarction patients. The ACE activity of individuals carrying D alleles is improved, causing the coronary plaque to become unstable, prone to rupture and form ulcers, which leads to the formation of thrombus ${ }^{57,58}$. This study was consistent with the results of the meta-analysis conducted by Zhou et al. ${ }^{59}$ in the Chinese population.

According to the results of Alazhary et al. ${ }^{60}$, no association between ACE I / D gene polymorphism and CAD in Saudi children was found, possibly due to regional and ethnic differences in this association. Although a study conducted in Japan indicated that ACE I / D gene polymorphism was associated with CAD, it was not linked to the severity of coronary artery stenosis, and the DD genotype was probably unrelated to the development of coronary artery stenosis ${ }^{61}$.

This study was divided into three groups according to the sample size. ACE I/D gene polymorphism was found to be related to the risk of CAD in subgroups with sample size ranging from 100 to 200 and greater than 200 , while no correlation was found in the subgroup with a sample size smaller than 100. As only two pieces of literature were included in the subgroup, the reliability of the consolidation effect values was low. Sensitivity analysis depicted there

TABLE 2 SUMMARY ODDS RATIO FOR THE ASSOCIATION OF ANGIOTENSIN-CONVERTING ENZYME INSERTION OR DELETION POLYMORPHISM AND CORONARY ARTERY DISEASE GROUPED BY SIZE

\begin{tabular}{|c|c|c|c|c|c|c|}
\hline \multirow[t]{2}{*}{$\begin{array}{l}\text { Study group } \\
\text { ( } N^{\circ} \text { of studies) }\end{array}$} & \multicolumn{2}{|c|}{$\begin{array}{l}N^{\circ} \text { of patients with DD } \\
\text { genotype/DI and II } N^{\circ} \text { of } \\
\text { patients }\end{array}$} & \multirow[t]{2}{*}{$\begin{array}{l}\text { Combined OR(95\%- } \\
\mathrm{Cl})\end{array}$} & \multicolumn{2}{|c|}{$\begin{array}{l}\mathrm{N}^{\circ} \text { of patients with II } \\
\text { genotype/ DI and DD } \mathrm{N}^{\circ} \\
\text { of patients }\end{array}$} & \multirow[t]{2}{*}{$\begin{array}{l}\text { Combined OR(95\%- } \\
\mathrm{Cl})\end{array}$} \\
\hline & $\begin{array}{l}\text { CAD } \\
\text { cases }\end{array}$ & $\begin{array}{l}\text { No CAD con- } \\
\text { trols }\end{array}$ & & CAD cases & $\begin{array}{l}\text { No CAD con- } \\
\text { trols }\end{array}$ & \\
\hline$<100$ cases $(2)$ & $23 / 68$ & $11 / 69$ & $2.303[0.772,6.870]$ & $34 / 57$ & $33 / 47$ & $0.792[0.422,1.488]$ \\
\hline $\begin{array}{l}100-200 \\
\text { cases (22) }\end{array}$ & $581 / 1211$ & 283/1298 & $2.311[1.883,2.836]$ & 439/1353 & $593 / 988$ & $0.499[0.406,0.612]$ \\
\hline $\begin{array}{l}\geq 200 \text { case } \\
(20)\end{array}$ & $1002 / 2734$ & $577 / 2627$ & $1.680[1.337,2.111]$ & $1222 / 2514$ & 1276/1928 & $0.745[0.632,0.879]$ \\
\hline $\begin{array}{l}\text { Test for het- } \\
\text { erogeneity }\end{array}$ & $\mathrm{Q}=7.54$ & $P=0.023$ & & $Q=11.98$ & $P=0.003$ & \\
\hline \multirow{2}{*}{$\begin{array}{l}\text { Combined } \\
\text { OR(95\%Cl) }\end{array}$} & 1.919 & {$[1.510,2.438]$} & & 0.659 & {$[0.505,0.860]$} & \\
\hline & $Z=5.33$ & $P<0.001$ & & $Z=3.07$ & $P=0.002$ & \\
\hline
\end{tabular}


was almost no change in the results after removing the largest sample, suggesting that the meta-analysis results were of good stability. The Egger regression analysis of funnel pattern represents the symmetry of graphs, and no publication bias exists.

In conclusion, ACE gene (I / D) polymorphism is related to the risk of CAD in Chinese Han population. In this study, recognized scientific methods were adopted, such as the joint use of multiple approaches to literature retrieval, the formulation of rigorous inclusion criteria, and the inclusion of documents. When we sifted through the literature, we took into account factors that may affect the results, and every study was in accordance with the law of genetic balance. The study population, which covers the Han population in most parts of China, has certain representativeness and guarantees the reliability of the meta-analysis results.

\section{RESUMO}

OBJETIVO: Investigar a associação entre o polimorfismo de inserção ou deleção do genótipo do gene da enzima conversora da angiotensina (ACE) e a susceptibilidade da etnia Han chinesa para a doença arterial coronariana (DAC). Métodos: Foi realizada uma pesquisa abrangente para o valor de OR (Odds Ratio) de contraste entre o grupo de polimorfismo de inserção ou deleção do genótipo do gene da enzima conversora da angiotensina (ACE) e o grupo de doença arterial coronariana (DAC) como um índice de eficácia. Uma meta-análise (Stata 12,0) foi utilizada para testar a heterogeneidade dos resultados, combinar os valores de eficácia, realizar análises de sensibilidade e de avaliação básica.

RESULTADOS: Um total de 638 estudos foram encontrados sobre a associação entre polimorfismos do gene da enzima conversora da angiotensina e doença arterial coronariana, dos quais 44 satisfaziam os critérios de inclusão. Nosso estudo incluiu 6246 casos e 5713 controles. O teste de heterogeneidade de cada estudo $(p<0,001)$ foi realizado seguindo o modelo de efeito randômico. $O$ valor de $O R$ para DD/ID+II foi 1,95, com 95\% de intervalo de confiança de (95\% CI) (1,66-2,29). O valor de OR para II/DI+DD foi 0,63, com 95\% IC $(0,55-0,72)$. A figura do funil é basicamente simétrica e os resultados da análise de sensibilidade foram estáveis.

CONCLUSÃo: O genótipo DD do gene da enzima conversora da angiotensina podem ser um fator de risco mais fraco para doença coronariana na população chinesa Han.

PalaVRas-ChaVe: Peptidil Dipeptidase A. Polimorfismo Genético. Doença da Artéria Coronariana. Metanálise.

\section{REFERENCES}

1. Cambien F, Poirier O, Lecerf L, Evans A, Cambou JP, Arveiler D, et al. Deletion polymorphism in the gene for angiotensin-converting enzyme is a potent risk factor for myocardial infarction. Nature. 1992;359(6396):641-4.

2. Cambien F, Evans A. Angiotensin I converting enzyme gene polymorphism and coronary heart disease. Eur Heart ). 1995;16(Suppl K):13-22.

3. Shafiee SM, Firoozrai M, Salimi S, Zand H, Hesabi B, Mohebbi A. Angiotensin converting enzyme DD genotype not associated with increased risk of coronary artery disease in the Iranian population. Pathophysiology. 2010;17(3):163-7.

4. Alazhary NM, Morsy MM, Al-Harbi KM. Angiotensin-converting enzyme gene insertion deletion (ACE I/D) polymorphism in Saudi children with congenital heart disease. Eur Rev Med Pharmacol Sci. 2015;19(11):202630.

5. Rigat B, Hubert C, Alhenc-Gelas F, Cambien F, Corvol P, Soubrier F. An insertion/deletion polymorphism in the angiotensin l-converting enzyme gene accounting for half the variance of serum enzyme levels. J Clin Invest. 1990;86(4):1343-6.

6. Sagnella GA, Rothwell MJ, Onipinla AK, Wicks PD, Cook DG, Cappuccio FP. A population study of ethnic variations in the angiotensin-converting enzyme I/D polymorphism: relationships with gender, hypertension and impaired glucose metabolism. J Hypertens. 1999;17(5):657-64.

7. Kario K, Kanai N, Saito K, Nago N, Matsuo T, Shimada K. Ischemic stroke and the gene for Angiotensin-converting enzyme in Japanese hypertensives. Circulation. 1996;93(9):1630-3.

8. Liu H, jia SB. The study of ACE gene polymorphisms in the patient with coronary heart disease in Hui ethnic and Han ethnic in Ningxia. Ningxia Med J. 2008;30(4):300-2.

9. Jing Z, Lin LU, Yong-Nian L, Zhan-Hai SU, Ying-Zhong Y. Association study between the angiotensin converting enzyme gene insertion/deletion polymorphism and Qinghai Han Chinese with congenital heart disease. Zhongguo Ying Yong Sheng Li Xue Za Zhi. 2016;32(6):499-503.
10. Xiang C, Wang Y, Wu S. Relationship between angiotensin converting enzyme gene and coronary heart disease diabetes and hypertension in Chinese. Chinese J Endocrine Metabolism. 1995(4):201-5.

11. Kario K, Kanai N, Saito K, Nago N, Matsuo T, Shimada K. Ischemic stroke and the gene for angiotensin-converting enzyme in Japanese hypertensives. Circulation. 1996;93(9):1630-3.

12. Gu H, Zhang H, Wang $Y$, liang $Y$. The relationship between insertion/deletion polymorphism of angiotensin-converting enzyme gene and coronary heart disease. J Capital University Medical Sciences. 1998;19(3):228-30.

13. Shi Y, Shan J, Li D. Association of angiotensin converting enzyme gene polymorphism with coronary heart disease in Chinese. Chin J Intern Med. 1998;37(12):815-8.

14. Qiu Y, Dai L, Shen C. Association of ACE gene polymorphism with coronary heart disease and hypertension. Zhejiang Medicine. 1999;(5):261-2.

15. Jia $Y$, Yang D, Yang Z. Analysis of angiotensin converting enzyme gene insertion/deletion polymorphism in patients with coronary heart disease. Jiangsu Medicine. 1999;(6):262-3.

16. Sui J, Li W, Peng $X$. The relationship between angiotensin-converting enzyme gene polymorphism and coronary heart disease. Tianjin Med J. 1999;27(12):707-10

17. Tan H, Zhang G, Huang C, Zhu K, Pan Q. Angiotensin 1-converting enzyme gene insertion/deletion polymorphism in patients with coronary artery disease and essential hypertension and its nucleotide sequence. Zhonghua Yi Xue Yi Chuan Xue Za Zhi. 1999;16(3):145-8.

18. Shi $Q$, Zhang $X$, Chen $L$. Relationship between coronary collateral circulation and angiotensin converting enzyme gene polymorphism of patients with coronary heart disease. Shandong Med J. 2000;40(17):1-3.

19. Xie Y, Zhang F, Wenzhu MA. Association between gene polymorphism of renin-angiotensin system and coronary heart disease. Acta Universitatis Medicinalis Nanjing. 2001;21(6):488-91. 
20. Chen J, Zhang J, Cheng L. Correlation of angiotensin-converting enzyme gene I/D polymorphism with coronary heart disease and the pathogenesis. J Clin Cardiol (China). 2001; 7(6):254-6.

21. Deng J, Zhou Y, Huang D, Yue J, Wang Y, Zhang X, et al. Relation between coronary artery disease and polymorphism of angiotensin converting enzyme gene. Sheng Wu Yi Xue Gong Cheng Xue Za Zhi. 2002;19(1):105-7.

22. Liu $H$, Chao L, Liao $S$. Relationship between angiotensin converting enzyme gene polymorphism, angiotensin converting enzyme activity and coronary heart disease. J Chinese Physician. 2002;4(5):483-5.

23. Su W, Zhu J, Zhang D, Yang Z. Relationship of angiotensin converting enzyme gene polymorphism with coronary artery disease. Acta Academiae Medicinae Nantong. 2002;22(2):145-8.

24. Zhu TB, Xu L, Yang ZJ. Analysis of relationship between three key gene polymorphisms of renin angiotensin system and coronary heart disease. Jiangsu Med J. 2002;28(10):745-6.

25. Zhang R, Wang $S$, Dai $Y$. Correlation between angiotensin converting enzyme gene polymorphism and coronary heart disease. I Pract Med. 2003;19(3):260-1.

26. Huang Z, Shi J, Zhang D. Correlation between angiotensin converting enzyme gene polymorphism and coronary heart disease. | Qiqihar Medical College. 2003;24(4):385-6.

27. Mao $Y$, Yuan Z, Huang $X$. The association between the deletion/insertion polymorphism of angiotensin converting enzyme and coronary heart disease in human Han population. Chin J Arterioscler. 2004;12(2):215-7.

28. Wang W, Ma Y. Association between I/D genetic polymorphism of angiotensin converting enzyme and the risk of coronary artery disease. I Clin Cardiol (China). 2004;20(6):325-7.

29. Zhu TN, Pan JX, Shen Z]. Renin-angiotensin system gene polymorphism and coronary thrombosis. J Exp Hematol. 2004;12(05):122-7.

30. Lin X, Wang M, Xia X. A study on relationship between the genetic polymorphism s of angiotensin system and the risk of coronary artery disease. | Chinese Physician. 2005;7(12):1593-5.

31. Wang $M$, Lin XX, Xia XM. Correlation between angiotensin system gene polymorphism and premature coronary heart disease. Clin Med China. 2006;(11):971-4.

32. Shi YP, Meng WH, Shan J. Relationship between angiotensin-converting enzyme gene polymorphism and severity of coronary heart disease and coronary atherosclerosis. I Zhejiang University (Medical Sciences). 2006;35(3):61-5.

33. Wang SQ. Association between angiotensin-converting enzyme and angiotensinogen gene polymorphisms and coronary heart disease. Nanchang University; 2006.

34. Yang L-X, Shi Y-K, Wang X-M. Clinical research of polymorphism of ACE gene and vessel reactive substances in coronary heart disease patients. J Pract Med. 2007;23(7):978-80.

35. Li L, Wang M, Zhao H, Wu S. Analysis of angiotensin converting enzyme gene polymorphism in patients with coronary heart disease. Shandong Med. 2008;42(2):41-2.

36. Jia Y-P, Guo X-H, Yang J-P. Association between gene polymorphism of renin-angiotensin system and coronary heart disease. Chin J Arterioscler. 2008;16(12):981-5.

37. Shi Y, Yang L, Qi F. Clinical research of polymorphism of ACE gene and severity of coronary artery stenosis in coronary heart disease. Chongqing Med. 2008;37(23):2660-2.

38. Zhao GD, Zhou PF, Cai ZY. Study on relationship between angiotensin-converting enzyme gene polymorphism and Chinese medical syndromes of coronary angina pectoris. Shanghai I Traditional Chinese Med. 2008;(7):8-10.

39. Yun ML, Zhong $J \mathrm{H}$, Zheng Y. Correlation of ACE gene polymorphisms with coronary heart disease in Han nationality in Hainan Province. China Tropical Medicine. 2009;9(4):625-7.

40. Yang $Z W$, Feng $X L$, Liang $X A$. Association between angiotensin-converting enzyme gene polymorphism and coronary heart disease in Han nationality in Xinjiang. Chinese J Gerontol. 2009;29(21):2718-9.

41. Chen J. Relationship of angiotensin-converting enzyme gene polymorphism with blood stasis syndrome in premature coronary heart disease. Human Academy of Chinese Medicine; 2009.
42. Xie JM, Feng XM, Qin WB. Relationship between the I/D polymorphism of angiotensin converting enzyme gene and coronary heart disease in Hans of Baotou area in Inner Mongolia. Chinese I Clinical Pathologist. 2009;1(1):6-8.

43. Liu JO, He LX. The polymorphism in intron16 of ace in the populations of CHD in Chinese Hans. Chinese J Birth Health \& Heredity. 2010;18(10):234.

44. Wang SQ, Wu YQ, Chen XS. Relationship between angiotensin-converting enzyme and angiotensinogen gene polymorphism and coronary heart disease. I Nanchang University (Medical Sciences). 2010;50(8):8-11.

45. Yang ZX, Jiang DJ, Liu K. ACE gene polymorphism and coronary heart disease study. Guide of China Medicine. 2011;9(36):22-3.

46. Peng J, Luo LY, Li T. Relationship between renin-angiotensin system gene polymorphism and ischemic chronic heart failure in aged coronary artery disease patient. Chinese Circulation J. 2011;26(2):93-6.

47. Yi SD, Gong ZH, Xiang DC. Correlation between angiotensin-converting enzyme gene I/D polymorphism and coronary heart disease. Shandong Med J. 2011;51(12):57-8.

48. Wang CL, Qi QX, Zhu YM. Correlation between angiotensin-converting enzyme gene I/D polymorphism in Han nationality patients with coronary heart disease in Qinghai Province. Qinghai Medical J. 2012;42(9):1-3.

49. Hu ZX, Hu SY, Li L. Impact of polymorphism of angiotensin converting enzyme gene on premature coronary heart disease with blood stasis syndrome. Chinese | Integrative Med Cardio-Cerebrovascular Disease. 2013;11(5):515-8.

50. Zhao P, Zhao H, Cao XY. Correlation between gene polymorphism of angiotensin-converting enzyme and coronary heart disease in population of Han nationality in Tangshan region. Chinese | Evidence-Based Cardiovascular Med. 2015;7(2):221-4.

51. Zhang XL, Liang ZY, Sun Y. Association of ACE gene I/D variant with coronary artery disease. Progress in Modern Biomedicine. 2016;16(6):1036-8.

52. Jing Z, Lin LU, Yong-Nian L, Zhan-Hai SU, Ying-Zhong Y. Association study between the angiotensin converting enzyme gene insertion/deletion polymorphism and Qinghai Han Chinese with congenital heart disease. Zhongguo Ying Yong Sheng Li Xue Za Zhi. 2016;32(6):499-503.

53. Dai SH. Association of serum levels of Angll, KLKI and ACE/KLKI polymorphisms with acute myocardial infarction. Shandong University;2017. p.1-57.

54. Karaali ZE, Agachan B, Yilmaz H, Isbir T. Angiotensin-converting enzyme I/D gene polymorphisms and effects of left ventricular hypertrophy in Turkish myocardial infarction patients. Acta Cardiol. 2004;59(5):493-7.

55. Gubaev KI, Nasibullin TR, Zakirova AN, Mustafina OE. Association of polymorphic markers I/D of gene ACE and A1166C of gene AT2R1 with ischemic chronic heart failure in the Russian and Tatar populations of Bashkortostan Republic. Genetika. 2006;42(12):1712-7.

56. Yu YY, Dong TW, Sui XF, et al. Advances in the relationship between ACE gene insertion/deletion polymorphisms and renin-angiotensin-aldosterone system and related cardiovascular diseases. Chinese I Clinicians. 2015(7):93-7.

57. Cambien F, Poirier O, Lecerf L, Evans A, Cambou JP, Arveiler D, et al. Deletion polymorphism in the gene for angiotensin-converting enzyme is a potent risk factor for myocardial infarction. Nature. 1992;359(6396):641-4.

58. Igic R, Behnia R. Properties and distribution of angiotensin I converting enzyme. Curr Pharm Des. 2003;9(9):697-706.

59. Zhou L, Xi B, Wei Y, Shen W, Li Y. Meta-analysis of the association between the insertion/deletion polymorphism in ACE gene and coronary heart disease among the Chinese population. | Renin Angiotensin Aldosterone Syst. 2012;13(2):296-304.

60. Alazhary NM, Morsy MM, Al-Harbi KM. Angiotensin-converting enzyme gene insertion deletion (ACE I/D) polymorphism in Saudi children with congenital heart disease. Eur Rev Med Pharmacol Sci. 2015;19(11):202630.

61. Lindpaintner K, Pfeffer MA, Kreutz R, Stampfer MI, Grodstein F, LaMotte $F$, et al. A prospective evaluation of an angiotensin-converting-enzyme gene polymorphism and the risk of ischemic heart disease. N Engl I Med. 1995,332(11):706-11. 